\title{
Aid Is Not Oil: Donor Utility, Heterogeneous Aid, and the Aid-Democratization Relationship
}

\author{
Sarah Blodgett Bermeo
}

\begin{abstract}
Recent articles conclude that foreign aid, like other nontax resources, inhibits political change in authoritarian regimes. This article challenges both the negative political effects of aid and the similarity of aid to other resources. It develops a model incorporating changing donor preferences and the heterogeneity of foreign aid. Consistent with the model's predictions, an empirical test for the period 1973-2010 shows that, on average, the negative relationship between aid and the likelihood of democratic change is confined to the Cold War period. However, in the post-Cold War period, nondemocratic recipients of particular strategic importance can still use aid to thwart change. The relationship between oil revenue and democratic change does not follow the same pattern over time or across recipients. This supports the conclusion that aid has different properties than other, fungible, resources.
\end{abstract}

Does foreign aid inhibit democratic change? Recent studies have lamented the political effects of foreign aid in authoritarian recipients. Aid, it is argued, provides governments in these countries with resources that can be used to thwart challenges to their authority. Morrison argues that aid has a similar effect to revenue from stateowned oil enterprises in decreasing the likelihood of regime transition. ${ }^{1}$ Djankov, Montalvo, and Reynal-Querol conclude that foreign aid may have a larger effect than oil revenue in preventing democratization. ${ }^{2}$ Ahmed concludes that aid and migrant remittances have similar effects, decreasing the likelihood of government turnover in authoritarian regimes. ${ }^{3}$ Bueno de Mesquita and Smith argue that aid, like revenue from oil, decreases the likelihood of leader turnover and dampens the democratizing effects of mass political movements in nondemocratic countries. ${ }^{4}$

I thank Faisal Ahmed, Kevin Morrison, Bruce Bueno de Mesquita, and Alistair Smith for making available data and do-files from their analyses, and for useful comments. I thank Tim Buthe, Charles Clotfelter, Joanne Gowa, Bruce Jentleson, Judith Kelley, Bob Keohane, David Leblang, Daniel Nielson, Sonal Pandya, Maggie Peters, Billy Pizer, Jonah Schulhofer-Wohl, seminar participants at Duke University and the University of Virginia, the editors and reviewers for comments on earlier versions of this work, and Michael Ross, Mike Tomz, and Erik Wibbels for discussions on related work.

1. Morrison 2009.

2. Djankov, Montalvo, and Reynal-Querol 2008.

3. Ahmed 2012.

4. Bueno de Mesquita and Smith 2010. 
These findings, if true, point to a dilemma for policy-makers in aid donors that value democratization. Democratic donors regularly interact with nondemocratic, developing countries. These donors offer aid in exchange for political favors and as a way to increase development. It would be difficult for policy-makers to be in the position where giving economic assistance necessarily results in a decreased probability that these countries will experience political improvements. Yet multiple, restrictive assumptions underlie results claiming a negative relationship between aid and democratization. It is important to ascertain whether this relationship is generally true and if it can be altered by the donor.

This study challenges the idea that aid operates like natural resource revenues in decreasing the likelihood of democratic change. The analysis starts with a model of donor utility in which a democratic donor considers whether to offer aid to a nondemocratic recipient in exchange for a costly policy favor. The model relaxes previous studies' key assumptions. It allows the donor to give a heterogeneous aid package made up of fungible aid, which adds to the recipient government's budget like revenue from oil, and/or nonfungible aid, which is used for purposes the recipient government would not otherwise have pursued. Donors can offer different combinations of fungible and nonfungible aid across both periods and recipients. In nondemocratic recipients, fungible aid is modeled as producing a negative externality for a democratic donor because it decreases the likelihood of democratic change. The magnitude of this externality can vary over time.

Given the negative externality, donors prefer to give nonfungible aid in nondemocratic recipients. However, the recipient government is assumed to prefer fungible aid so that a given favor can be purchased with less fungible aid than nonfungible aid. The donor decides on the composition of aid after considering the size of the externality relative to the increased expenditure needed to buy a favor with nonfungible aid. Recipients are modeled as heterogeneous, including those of average and high strategic importance to the donor, and strategic importance can vary across periods and across recipients within a period. According to the model, aid to an authoritarian recipient will contain lower amounts of fungible aid as strategic importance declines and/or desirability of democratic change increases. This implies that the likelihood of a recipient leader successfully using aid to prevent democratic change varies over time and across recipients.

Hypotheses are derived from the model and tested on a data set consisting of 129 developing countries over the period 1973-2010. The first hypothesis posits that aid is less likely to hinder democratic change in the post-Cold War period. Many developing countries saw their geopolitical strategic importance decrease with the end of the bipolar power struggle of the Cold War. Donors also increased their emphasis on democratization. Both of these changes suggest that democratic donors are less willing to give aid that will prop up dictators in the post-Cold War period.

The second hypothesis acknowledges the likelihood that, even with declining average strategic importance for developing countries in the post-Cold War period, some individual states will continue to be of high strategic value. Recipients in positions of importance receive more fungible aid. This hypothesis 
states that even in the post-Cold War period, aid can decrease the likelihood of democratic change in the most strategically important recipients.

The statistical analysis provides strong evidence that the relationship between aid and democratic change varies over time and recipients. During the Cold War, higher levels of aid were associated with a lower probability of democratic change. There is no evidence that this negative relationship between aid and democratic change exists, on average, in the post-Cold War period. However, for recipients of high strategic importance, the negative association between aid revenue and the likelihood of democratic change is evident after the end of the Cold War.

An innovation of the model is the ability of donors to vary the fungibility of aid over time and across recipients. As the extent to which aid is fungible is contested, it is important to test the plausibility of this assumption. For each hypothesis the relationship between aid and democratic change is compared with the relationship between oil revenue and democratic change. If aid is a predominantly fungible resource, then the relationship between aid and democratic change should be similar to the relationship between oil revenue (a fungible form of government income) and democratic change.

The empirical comparison shows the dissimilarity between aid and oil revenue. Oil revenue is associated with decreased democratic change in the post-Cold War period whereas, on average, foreign aid is associated with less democratic change only during the Cold War. The relationship between aid and democratic change varies based on the strategic importance of the recipient to donors; for oil revenue no such difference across strategic importance is observed. The differences between aid and oil revenue across time and recipients are consistent with a model in which donors are able to change the composition of aid to respond to strategic realities and their own preferences; they are inconsistent with the treatment of aid as an always fungible resource.

The results of this study are at odds with several recent articles and it is important to understand the source of differences in the empirical findings. To address this issue, as a final step in the analysis I revisit the studies of Morrison, ${ }^{5}$ Bueno de Mesquita and Smith, ${ }^{6}$ and Ahmed ${ }^{7}$ using replication data provided by the authors. Taken together, these studies present what appears to be a robust finding of the negative political consequences of foreign aid in authoritarian regimes. In each case a reexamination of the original analyses calls into question the negative relationship between foreign aid and the likelihood of political change, and the similarity between aid and other forms of resources.

Contrary to the recent trend toward aggregation of nontax resources in scholarly literature, aid is not oil. Foreign aid comes from donors that have strategic priorities and preferences regarding democratic change. They also have tools to provide a 
heterogeneous basket of aid that can vary across time and recipients. Because of this, there is nothing inevitable about the relationship between aid and the likelihood of democratic change. Donors play a key role in determining this relationship, varying the composition of aid to suit their own purposes. In studying the relationship between aid, oil, and other variables of interest, scholars and policy-makers should account for these differences and resist the temptation to aggregate nontax resources into a single category.

\section{Aid, Oil, and Political Change}

A government with access to large sums of revenue from oil and gas is not dependent on its citizens for funding. It is therefore less accountable and faces less pressure to democratize. ${ }^{8} \mathrm{~A}$ considerable body of literature has emerged examining the political curse associated with natural resources, not all of it in agreement regarding the resources' effects. ${ }^{9}$

In recent years, scholars have argued that foreign aid can create the same political curse associated with oil. Morrison claims that similarities between aid, oil revenue, and other forms of nontax resources justify their aggregation to form a single measure of nontax revenue available to the government. ${ }^{10}$ Others are more cautious about equating aid and oil revenue, arguing that aid has unique properties because it is given by an outside source, the donor. ${ }^{11}$

Formal treatments of the relationship between aid and either leader or regime survival tend to model the relationship between a recipient government and its citizenry; aid is simply added to the budget constraint of recipient governments. Smith models the likelihood of revolutionary onsets and the response of the government as a function of "unearned income," which includes revenue from oil as well as foreign aid. ${ }^{12}$ There is no heterogeneity in unearned income in the model — it is simply added to the government's budget. Ahmed adds a variable for aid to a model relating institutional quality to the quantity of migrant remittances. ${ }^{13}$ Once again, the main focus is on the interaction between the recipient government and its citizenry; aid is simply added to the government budget. Morrison allows for donors to give either conditional or unconditional aid, but once given, aid enters directly into the government budget. ${ }^{14}$

8. See Ross 2001 and 2012, for a discussion of the links between oil and authoritarianism, including an excellent overview of the literature and potential causal pathways. On the link between taxation and democracy, see Tilly 1990.

9. For example, see Acemoglu et al. 2008; Boix 2003; Dunning 2008; Epstein et al. 2006; Goldberg, Mvukiyehe, and Wibbels 2008; Haber and Menaldo 2011; Jensen and Wantchekon 2004; and Ramsay 2011.

10. Morrison 2009.

11. Collier 2006.

12. Smith 2008.

13. See Ahmed 2012; and Abdih, Chami, and Dagher 2012.

14. Morrison 2007. 
Bueno de Mesquita and Smith model the interaction between donors and recipients in which donors seek to extract a policy concession from the recipient government in exchange for aid. They assume aid is a fungible payment from the donor to the recipient government. ${ }^{15}$

The relationship between aid and the likelihood of political change in recipients has also been a fertile area for empirical research. Dunning shows that aid to Africa is associated with increased democracy in the post-Cold War period, but not earlier. ${ }^{16}$ Djankov, Montalvo, and Reynal-Querol ${ }^{17}$ and Morrison ${ }^{18}$ find that aid decreases the likelihood of regime change, whereas Bueno de Mesquita and Smith $^{19}$ and Ahmed ${ }^{20}$ find that aid increases the likelihood of survival for individual leaders or governments. Knack finds no significant relationship between foreign aid and democratic change. ${ }^{21}$ Wright concludes that autocratic leaders who expect to remain in office after democratization respond positively to promises of increased aid in exchange for democratic change. ${ }^{22}$ Kono and Montinola find different effects of long-term and short-term aid on the likelihood of leader survival, with continued aid helping to entrench autocrats in the long run. ${ }^{23}$ I have shown elsewhere that in the post-Cold War period, aid from oil-rich, autocratic donors entrenches dictatorships, whereas aid from democratic donors does not. ${ }^{24}$ Kersting and Kilby highlight the importance of aid conditionality, and find differences in the aid-democratization relationship based on the geopolitical importance of the recipient. ${ }^{25}$

\section{Strategic Importance, Donor Preferences, and Heterogeneous Aid}

This section models the utility of a democratic donor when allocating aid to a nondemocratic recipient government in exchange for a policy favor. This ignores some aspects of aid, such as situations in which donor priorities for aid intersect with recipient government priorities, rather than being a payment for favors rendered. This simplification is undertaken for two reasons. First, situations of aid-for-policy deals represent a difficult case. When a donor needs a favor from the recipient, it is in less of a position to dictate how aid is spent. It is in these situations that we are most likely to observe aid dampening the likelihood of democratization. Second,

15. Bueno de Mesquita and Smith 2009.

16. Dunning 2004.

17. Djankov, Montalvo, and Reynal-Querol 2008.

18. Morrison 2009.

19. Bueno de Mesquita and Smith 2010.

20. Ahmed 2012.

21. Knack 2004.

22. Wright 2009.

23. Kono and Montinola 2009.

24. Bermeo 2011.

25. Kersting and Kilby 2014. 
influential models showing negative political effects of aid, such as Bueno de Mesquita and Smith, focus on instances in which aid is given as part of a policy deal. ${ }^{26}$ The question addressed here is whether relaxing assumptions underlying existing studies yields the possibility of a different relationship between aid and democratic change, even in cases most likely to see negative political effects of aid. The most notable innovations in this study include modeling aid as heterogeneous, made up of both fungible and nonfungible resources, and allowing donors to experience a negative externality when aid makes democratization in a recipient less likely.

\section{Variation in Strategic Importance and Donor Preferences}

During the Cold War, dictators on the "right" side of the bipolar power struggle were rewarded with large amounts of aid. An example of this is the regime of Mobutu Sese Seko in Zaire (now Democratic Republic of Congo), which received hundreds of millions of aid dollars a year in exchange for supporting the fight against communists in the Angolan civil war. There was probably little doubt at the time that Mobutu was not using the money to "vaccinate children or train teachers." 27 Donors would likely have preferred that Mobutu help fight communism and that aid be used for beneficial or at least not harmful programs. However, strategic considerations overshadowed donor preferences and the money continued to flow. The collapse of the Soviet Union brought about change; as Brautigam and Knack note "the end of the Cold War allows the United States and other donors to target aid more selectively, rather than using aid to strengthen corrupt but geopolitically useful autocracies." 28

The end of the Cold War brought not only the demise of strategic importance for many developing countries but an increased emphasis on democratization for many democratic aid donors. As Kelley argues, "the [cold] war's end freed Western countries to push for democratic changes. Indeed, democracy increasingly came to be seen as strengthening rather than undermining security interests." 29 The possibility of impeding democratization can create a negative externality for democratic donors in any period. However, the magnitude of this externality and the extent to which it is trumped by strategic considerations likely changes with the transition from the Cold War to post-Cold War period.

Although the strategic importance to donors of the average developing country fell with the end of the Cold War, in any period there will be recipients of particular geopolitical significance. Even in the post-Cold War period, there will be situations where strategic importance takes precedence over preferences for democratization. ${ }^{30}$ Similar arguments have linked the importance of the recipient to the effectiveness of

26. Bueno de Mesquita and Smith 2009.

27. Radelet 2003, 107-8.

28. Brautigam and Knack 2004, 275.

29. Kelley 2008, 229.

30. Kersting and Kilby 2014 make a similar point. 
conditionality at the International Monetary Fund (IMF) ${ }^{31}$ and World Bank. ${ }^{32}$ The model developed in this study incorporates variation in strategic importance both across periods and across recipients within periods.

\section{Heterogeneous Aid}

An innovation of the model is that it allows for two types of aid: fungible and nonfungible. Fungible aid is defined as either accruing directly to the recipient government or financing programs the recipient government would have undertaken in the absence of aid, thus freeing up resources for other purposes. Nonfungible aid is defined as providing programs/services the recipient government would not have undertaken in the absence of aid that do not free up government finances for other purposes.

Recipient governments prefer fungible aid, whereas democratic donors prefer to provide nonfungible aid to nondemocratic recipients to minimize the likelihood that aid inhibits democratic reform. For a given recipient, the donor weighs the magnitude of the negative externality associated with decreased likelihood of democratic change against the greater effectiveness of fungible aid for buying favors from the government. When the allocation decision results in high levels of fungible aid, it increases the likelihood that aid will be associated with less democratic change.

How realistic is the idea that donors can alter the composition of their aid between fungible and nonfungible? Empirical evidence of aid fungibility is mixed. ${ }^{33}$ Collier suggests that in some recipients the likelihood of donor development projects replacing programs funded by the recipient government is low because the government is unable/unwilling to undertake any development projects in the absence of aid. ${ }^{34}$ Related work on the effects of aid suggests that these differ with regard to the type of assistance, time period, and/or identity of the donor, suggesting limits on fungibility. ${ }^{35}$ Recent studies and policy statements are consistent with donor attempts to limit fungibility in certain types of recipients. I show that the composition of aid in poorly governed countries suggests it may be less fungible than in well-governed recipients, ${ }^{36}$ and Dietrich demonstrates that donors bypass governments when giving aid in recipients with bad governance. ${ }^{37}$ Hilary Benn, former Secretary of State for International Development in the United Kingdom, puts a policy voice on these findings when he claims that the UK "finds practical ways to ensure that aid cannot be siphoned off. We can and do directly fund ... 'concrete things'... Or we can earmark aid for a particular programme of work in a sector and account for that money independently through a separate bank

31. See Stone 2002 and 2008.

32. Kilby 2009.

33. See Feyzioglu, Swaroop, and Zhu 1998; and Pack and Pack 1990.

34. Collier 2006.

35. See Clemens et al. 2012; Bearce and Tirone 2010; and Bermeo 2011.

36. Bermeo 2010.

37. Dietrich 2013. 
account. We do this in the education sector in Kenya, where the financial risk of handing over money to the government is too great." ${ }^{38}$ Taken together, this suggests that although it is likely some aid is fungible, it is also likely that not all aid is fungible.

The ability to compare aid with more clearly fungible streams of government resources allows the question of fungibility to become a testable premise of the model, rather than an assumption accepted (or not) in the absence of evidence. I examine the relationship between oil revenue-a resource that often accrues directly to the government-and democratic change to see whether the oil revenue-democratic change and aid-democratic change relationship show similar trends over time and recipients. If aid is a predominantly fungible resource, it should have properties similar to oil revenue.

\section{Modeling Foreign Aid}

The model developed in this study is restricted to cases of a democratic donor considering aid to a nondemocratic recipient because these are the instances where donor concern regarding possible democratization seems most relevant. It adopts a similar structure to that used by Bueno de Mesquita and Smith: the donor offers a recipient aid in exchange for a policy favor that is costly for the recipient government to enact, what the authors refer to as an "aid-for-policy" deal. ${ }^{39}$ Examples of this include the United States buying votes at the UN with aid ${ }^{40}$ and Switzerland using aid to buy votes supporting its membership on the executive board of international financial institutions. ${ }^{41}$ The offer is made and accepted only if it is incentive compatible for both donor and recipient.

A donor government $(d)$, when deciding on a potential aid package to a recipient $(x)$, will compare its utility when giving the aid to a baseline utility without giving the aid. This baseline utility can be written as follows:

$$
U_{d t, \text { no aid }}=S_{d t}\left(R_{d t}\right)
$$

where $S_{d t}$ is the donor's utility function at time $t$ for all purposes other than aid to the recipient and $R_{d t}$ is the total amount of resources available to the donor government.

Two different types of recipients are modeled: those of average and high strategic importance. Recipients of average strategic importance are in a position to provide the donor with $\omega_{t}$ in utility, where $\omega_{t}$ is the benefit the donor derives from the policy concession and can vary over time as the international political climate changes. Recipients of high strategic importance in any period can supply the donor with $\theta$ in additional utility.

38. Open exchange between Bill Easterly and Hilary Benn in Easterly 2006.

39. Bueno de Mesquita and Smith 2009.

40. Carter and Stone 2015.

41. Vreeland 2011. 
If the donor offers an aid package, the resources available to the donor government for other purposes are reduced by the amount of the aid, $A$. Aid can be a mixture of fungible aid $(F)$ and nonfungible aid $(N)$, such that the resources expended (and therefore not available for other purposes) are $A=F+N$ and $\frac{\partial S_{d t}}{\partial F}=\frac{\partial S_{d t}}{\partial N}$. Fungible aid produces a negative externality for the donor by decreasing the likelihood of democratic change in the recipient. The magnitude of the externality is captured by $\beta_{t} F ; \beta_{t}$ can vary over time as donor preferences regarding democratization change. ${ }^{42}$

The donor's utility function at time $t$ if it enters into an aid-for-policy deal with the recipient can be written as follows:

$$
U_{d t, \text { aid }}=\omega_{t}+\gamma_{x t} \theta+S_{d t}\left(R_{d t}-A\right)-\beta_{t} F
$$

where $\gamma_{x t}$ is an indicator variable that takes the value of 1 when the recipient is of high strategic importance and 0 otherwise. The aid-for-policy deal is incentive compatible for the donor if $U_{d t, \text { aid }} \geq U_{d t, \text { no aid }}$ :

$$
\omega_{t}+\gamma_{x t} \theta+S_{d t}\left(R_{d t}-A\right)-\beta_{t} F \geq S_{d t}\left(R_{d t}\right)
$$

Given the externality, the donor would prefer to give $N$ rather than $F$ in nondemocratic recipients. The magnitude of the cost associated with giving a unit of $N$ is captured by (where $\left|\frac{\partial S_{d t}}{\partial A}\right|$ is negative), whereas the magnitude of the larger cost associated with a unit of $F$ is $\left|\frac{\partial S_{d t}}{\partial A}-\beta_{t}\right|$. However, the point of the deal is to buy a policy concession from the recipient government, which is assumed to prefer fungible over nonfungible aid. Given this, it takes less $F$ to purchase the favor than $N$. To decide on the right mix of $F$ and $N$ to offer (if any), the donor must also consider the situation from the recipient's point of view.

The utility of the recipient government without aid is a function of the amount of resources it has to spend:

$$
U_{x t, \text { no aid }}=S_{x t}\left(R_{x t}\right)
$$

where $R_{x t}$ represents total resources to the recipient government without aid. If the recipient government accepts an aid-for-policy deal, it incurs a cost associated with agreeing to the donor's demands for $\omega_{t}$ and $\theta$ :

$$
C=C_{\omega}+\gamma_{x t} C_{\theta}
$$

where the recipient incurs the cost $C_{\theta}$ only if it is strategically important to the donor $\left(\gamma_{x t}=1\right)$.

42. Given the focus of the analysis, the externality is assumed to be in the form of decreased likelihood of democratization only. It could be broadened to include any additional negative aspects of giving $F$ relative to $N$, such as a reduction in development outcomes when aid is fungible. 
The donor supplies the recipient with aid in the form of $F$ and $N$ to "produce" enough utility for the recipient government to undertake the desired action. Fungible aid, $F$, directly increases the amount of resources the recipient government has at its disposal. Nonfungible aid does not free up government resources but may still provide a benefit to the recipient government-it may support programs the government values but would not have been able to/chosen to provide itself. The recipient government's utility under the aid-for-policy deal is given as follows:

$$
U_{x t, \text { aid }}=S_{x t}\left(R_{x t}+F\right)+V_{x t}(N)-C
$$

where $V_{x t}(N)$ is a function transforming nonfungible aid into utility. The recipient government is assumed to (weakly) prefer fungible to nonfungible aid, so that $\frac{\partial U_{x t}}{\partial F} \geq \frac{\partial U_{x t}}{\partial N}$, or (equivalently) that $\frac{\partial S_{x t}}{\partial F} \geq \frac{\partial V_{x t}}{\partial N} \cdot{ }^{43}$ An aid-for-policy deal will be incentive compatible for a recipient when the following holds:

$$
S_{x t}\left(R_{x t}+F\right)+V_{x t}(N)-C \geq S_{x t}\left(R_{x t}\right)
$$

In a situation of perfect information, the donor can offer the recipient a basket of $F$ and $N$ that produces just enough increase in utility to compensate for the cost of granting concessions, so that equation (7) holds with equality. Obviously, the more highly the recipient values each unit of $F$ and/or $N$, the less aid it will take to cover the cost of granting the concession; in these cases it is most likely that an aid-for-policy deal can be arranged that is incentive compatible to both donor and recipient. This suggests that small countries may be "bought" more cheaply because any given amount of funding will provide more benefit per person, and thus be more valuable, when there are fewer people. Additionally, assuming concave preferences for funding, poorer countries will have a higher value for each additional unit of funding, implying that buying favors will be cheaper when $R_{x t}$ is lower. These are similar to conclusions reached by Bueno de Mesquita and Smith ${ }^{44}$ and Stone,${ }^{45}$ and therefore not the focus here.

The novelty in this model lies in the donor's ability to give both fungible and nonfungible aid, and the negative externality imposed on the donor when it gives fungible aid. The higher the value of $\beta_{t}$, the more costly it is for the donor to give $F$ relative to giving $N$. And, the greater the distance between $\frac{\partial S_{x t}}{\partial F}$ and $\frac{\partial V_{x t}}{\partial N}$, the less valuable $N$ is to the recipient relative to $F$. To determine whether to offer the aid-for-policy deal to a recipient, the donor will compare its utility without the deal with the utility it would

43. This is a simplification that may not always hold. In some cases a recipient may place a higher value on (nonfungible) technical cooperation if it supplies expertise that cannot be purchased domestically. In those cases the donor should supply this first, before switching to fungible aid or other types of nonfungible aid. As long as technical cooperation alone is not enough to buy the policy deal, the inequality will be true for the relevant portion of the analysis.

44. Bueno de Mesquita and Smith 2009.

45. Stone 2010. 
receive maximizing equation (2) subject to the recipient's incentive compatibility constraint (equation 7). From the first-order conditions of this constrained optimization, the donor will minimize costs when the combination of $F$ and $N$ offered satisfy the following:

$$
\frac{\frac{\partial S_{x t}}{\partial F}}{\frac{\partial V_{x t}}{\partial N}}=\frac{\frac{\partial S_{d t}}{\partial A}-\beta_{t}}{\frac{\partial S_{d t}}{\partial A}}
$$

The left-hand side of equation (8) is the marginal rate of substitution between $F$ and $N$ for producing utility in the recipient; the right-hand side is the ratio of the costs to the donor from foregone utility of providing $F$ relative to $N$. Equation (8) will hold when cost minimization is achieved through a mix of $N$ and $F$ (an interior solution). Corner solutions, in which the cost-minimizing aid package consists of only $N$ or $F$ are also possible. The donor will offer the recipient a package of aid if the minimum cost combination of $F$ and $N$ which satisfy equation (7) also satisfy equation (3).

Equation (8) highlights the relatively complex relationship between donor utility, recipient utility, and the negative externality $\beta_{t}$. First, there may be some recipients for which the left-hand side of equation (8) is always greater than the right-hand side: in this case if a deal is incentive compatible for the donor it will consist of only fungible aid (corner solution). In other cases, where the left-hand side is lower than the right-hand side for low levels of aid, the donor will include only $N$ in the aid package up until the point where the next unit of $N$ adds less value in terms of recipient utility than is saved for the donor by giving $N$ rather than the higher cost $F$. If this point is reached before incentive compatibility is met for the recipient, the donor will minimize costs by providing a mixed package of $N$ and $F$ that satisfies equation (8), if it provides any aid at all.

Because $S_{d t}\left(R_{d t}-A\right), S_{x t}\left(R_{x t}+F\right)$, and $V_{x t}(N)$ are each assumed to have the usual concave properties of utility functions, the tradeoff of $N$ for $F$ that satisfies equation (8) changes as $N$ and $F$ change. An example can help illustrate the point. Suppose the recipient is at a point on its utility function where the next unit of utility can be purchased with 3 units of $N$ or 2 units of $F$. Each unit of $N$ costs the donor $\left|\frac{\partial S_{d t}}{\partial A}\right|$ in utility and each unit of $F$ costs $\left|\frac{\partial S_{d t}}{\partial A}-\beta_{t}\right| \cdot{ }^{46}$ If $\frac{\partial S_{d t}}{\partial A}<\beta_{t}$ for the extra unit of $A$ required to purchase the same utility with $N$ rather than $F$, then the donor will supply $N$; otherwise it will supply $F$. As the recipient receives more $N$ the marginal utility increase associated with additional $N$ will decline, meaning more $N$ will be needed to offset a unit of $F$. On the donor side, as more $A$ is supplied the decrease in $S_{d t}\left(R_{d t}-A\right)$ for each additional unit of $A$ increases, meaning the donor is less willing to trade off increased $A$ in the form of $N$ to avoid the externality associated with $F$.

\footnotetext{
46. Note that $\frac{\partial S_{d t}}{\partial A}<0$ so that the magnitude of the foregone utility for the donor is higher for a unit of $\mathrm{F}$
than a unit of $\mathrm{N}$.
} 
Several useful insights come from this setup. Beginning with recipients of average importance, envision a heterogeneous group deriving varying levels of utility from $F$ and $N$ at an initial time, period 1. A shock occurs, such as the end of the Cold War, decreasing strategic importance for the average recipient, $\omega_{i}$; this shock moves the countries into period 2 . Within these average recipients, some were right at the incentive compatibility constraint for the donor in period 1 , whereas others were well inside it. Those who were at or near the donor's incentive compatibility constraint will now fall outside of it when the value of $\omega_{t}$ falls, and will no longer be offered an aid-forpolicy deal. Because recipients requiring the most $F$ at any point are the most expensive for the donor, they are the most likely to be dropped from aid deals in period 2. Thus, the remaining pool of recipients receiving a deal will receive less fungible aid on average than those in period 1, and a higher proportion of their aid package will be nonfungible aid. The changing strategic importance leads to the expectation of a changing composition in aid, away from fungible aid. This follows from the fact that some recipients are dropped from period 1 to period 2, and holds even if the composition of aid to the remaining recipients is unchanged.

It is also useful to contemplate a scenario under which the composition of aid given to remaining recipients is altered by the donor. This could result from an increase in the size of the negative externality for giving fungible aid to a dictatorship, $\beta_{t}$, in the move from period 1 (for example, Cold War) to period 2 (for example, post-Cold War). An increase in $\beta_{t}$ increases the cost of $F$ relative to $N$. For those recipients that remain incentive compatible in period 2, aid will shift away from the more costly $F$ toward the relatively cheaper $N$. Importantly, given recipient preference for $F$ over $N$, this will mean an increase in $A$ is necessary to maintain the minimum level of benefit to make the deal incentive compatible for the recipient. Holding strategic importance constant, for recipients still receiving an aid package total aid increases while fungible aid decreases. ${ }^{47}$ This decline in fungible aid suggests a decreased ability for recipient governments to use aid to thwart democratic change because less aid accrues to them for their discretionary use.

Within any period, the situation is different for recipients of high strategic importance; in general they will receive a higher proportion of their aid package as fungible aid than recipients of average strategic importance. This follows from the fact that these recipients require more aid to grant the higher-cost policy concessions, and returns diminish more quickly for $N$ than for $F$ because of the larger number of potential uses for $\mathrm{F}$. Thus as aid increases, the difference between the amount of utility purchased with $N$ and $F$ also increases; minimizing costs as required by equation (8) will involve giving a larger proportion of the aid package in the form of $F$. It is still true that an increase in $\beta_{t}$ across periods will cause the donor to shift toward $N$. However, within any period the composition of aid for recipients of high strategic importance is weighted more toward fungible aid. The different composition of aid

47. The increase in $\beta_{t}$ can also lead to a further decrease in recipients if it causes more potential aid deals to become incentive incompatible. 
across recipients of average and high strategic importance suggests that the relationship between aid and democratic change may also vary across these groups of countries within a time period.

\section{Hypotheses}

Arguments that aid prevents democratic change rest on the assumption that aid is a fungible resource available to the recipient government; this assumption is relaxed in this study. The hypotheses are set up to test for differences in the aid-democratic change relationship over time and across recipients, as suggested by the model. They also examine the relationship between oil revenue and democratic change, to probe whether aid has properties similar to fungible resources.

\section{Variation over Time}

With the move from the Cold War to the post-Cold War period, average strategic importance $\left(\omega_{t}\right)$ declined and distaste for authoritarianism $\left(\beta_{t}\right)$ increased. In response to this, donors give less fungible aid on average, leading to the hypothesis:

H1A: Foreign aid is less likely to inhibit democratic change in the post-Cold War period.

If observed changes in the aid-democratic change relationship are attributable to a shift away from fungible aid, then the same changes should not be observed for fungible government resources, such as oil revenue. Thus the model implies the following hypothesis:

H1B: Changes over time in the relationship between foreign aid and the likelihood of democratic change are not observed for the relationship between oil revenue and the likelihood of democratic change.

\section{Variation Across Recipients}

Regardless of average changes across time, there are recipients in any period that are not fully democratic yet are in a position to provide a democratic donor with favors of high strategic importance. The model incorporates this heterogeneity, allowing for the greater benefit to the donor $(\theta)$ and cost to the recipient $\left(C_{\theta}\right)$ in these situations. As shown, this results in an increase in fungible aid relative to recipients of average importance, both in absolute levels and as a proportion of the total aid package. This makes it more likely that the government in recipients of high strategic importance can use aid resources to impede democratic change, suggesting the following hypothesis: 
H2A: Aid is more likely to inhibit democratic change in recipients of high strategic importance.

As with variation over time, insights can be obtained by comparing the relationship between aid and democratic change with that between oil revenue and democratic change. There is no reason that being of only average strategic importance to outside donors should make a country less able to use fungible resources to prevent democratic change. If a difference in the aid-democratic change relationship between recipients of average and high strategic importance is the result of a difference in aid fungibility across these two types of recipients, then the same difference should not be observed in the oil revenue-democratic change relationship, implying the following hypothesis:

H2B: Differences across recipient type in the relationship between foreign aid and the likelihood of democratic change are not observed for the relationship between oil revenue and the likelihood of democratic change.

\section{Data and Results}

The hypotheses are tested using a data set that includes 129 developing countries and covers the period $1973-2010 .{ }^{48}$ Results of multiple alternative specifications are discussed to probe the robustness of the main findings.

\section{Dependent Variable}

The dependent variable is an indicator of democratic change coded using changes in a country's score on the Polity2 measure from the Polity IV project. ${ }^{49}$ The Polity2 measure runs from -10 to 10 , with higher numbers representing greater democratization. The dependent variable equals 1 if a country experienced an increase in its Polity 2 score of three points or more from $t-1$ to $t$ and 0 otherwise. The sample is restricted to countries with a Polity2 score of 7 or lower in $t-1$ because scores higher than that cannot increase by three points. Unlike Morrison, which considers a three-point change in the Polity score regardless of direction, ${ }^{50}$ the main analysis in this study examines only movements toward democratization. As Ulfelder notes, failure to control for the direction of the change conflates democratic transitions with democratic failures. ${ }^{51}$ For regressions covering the Cold War period, the

48. The online appendix includes further details on the construction of the data set.

49. Marshall and Jaggers 2011.

50. Morrison 2009.

51. Ulfelder 2007. 
dependent variable takes the value of 1 in 78 of 1,645 observations (4.7 percent); for the post-Cold War the value equals 1 for 71 of 1,666 observations (4.3 percent).

I chose an indicator for a three-point change as the main dependent variable because it is less blunt then an indicator for full democratization. The question here is whether receiving more aid decreases the chance that a country will move toward democratization. This measure avoids situations in which movement from just below to just above a cutoff for democratization counts as a change, whereas much larger movements below the cutoff do not. Results are tested for robustness using different measures of democratic change.

\section{Key Independent Variables}

Data on aid are from the Organisation for Economic Cooperation and Development (OECD), which records aid commitments by year for all recipients from OECD donors and other donors that choose to report to it. The model I developed relates to democratic donors only; there is no assumption that authoritarian donors experience a negative externality from entrenching dictatorships. Therefore, total aid commitments minus any commitments from authoritarian donors are used. Aid is divided by population as reported in the Penn World Table, v.7.152 and the log of one plus aid per capita is used as the measure of foreign aid. A measure of the log of oil wealth per capita is also included. ${ }^{53}$ Aid, oil, and other independent variables are lagged by two years to ensure that they capture the value prior to the change from $t-1$ to $t$ used to construct the dependent variable.

\section{Control Variables}

The log of income per capita and growth rate of income per capita (lagged one year because it is a growth rate) from the Penn World Table v.7.1 are included. Because a country's value in year $t-1$ on the Polity 2 scale may affect its ability to further democratize, a lagged value for the Polity 2 variable is included. Also included is a variable for previous transitions that counts the number of times a country has had a positive change of three points or more on the Polity2 index in the previous forty years because previous experience with democracy may be important. A time trend variable for year is included.

\section{Aid, Oil, and Democratic Change}

Table 1 presents the main tests for $\mathrm{H} 1 \mathrm{~A}$ and $\mathrm{H} 1 \mathrm{~B}$, using a logit model with AGE, AGESQUARED, and AGE-CUBED variables included to account for temporal dependence. ${ }^{54}$

52. Heston, Summers, and Aten 2012.

53. Ross 2012.

54. Carter and Signorino 2010 show that this approximates a hazard model. 
Model 1 reports results for the entire time period, 1973-2010. Model 2 reports results for the Cold War period. Because of the two-year lag, 1990 was chosen as a break point: aid for observations in 1990 was committed in 1988, prior to the end of the Cold War. ${ }^{55}$ Model 3 includes observations for 1993-2010. ${ }^{56}$ Standard errors are clustered on country; $p$-values are in parentheses.

TABLE 1. Aid, oil, and democratic change

\begin{tabular}{|c|c|c|c|}
\hline & $\begin{array}{l}\text { All years } \\
\text { Model } 1\end{array}$ & $\begin{array}{l}\text { Cold War } \\
\text { Model } 2\end{array}$ & $\begin{array}{l}\text { Post-Cold War } \\
\text { Model } 3\end{array}$ \\
\hline LN AID PER CAPITA (lag 2) & $\begin{array}{c}-0.058 \\
(0.43)\end{array}$ & $\begin{array}{c}-0.235 * * \\
(0.01)\end{array}$ & $\begin{array}{c}0.176 \\
(0.22)\end{array}$ \\
\hline LN OIL REV PER CAPITA (lag 2) & $\begin{array}{c}-0.081 * * \\
(0.03)\end{array}$ & $\begin{array}{r}-0.067 \\
(0.20)\end{array}$ & $\begin{array}{c}-0.136^{* *} \\
(0.03)\end{array}$ \\
\hline LN INCOME (lag 2) & $\begin{array}{l}0.179 * \\
(0.06)\end{array}$ & $\begin{array}{l}0.383 * * * \\
(0.00)\end{array}$ & $\begin{array}{c}0.143 \\
(0.46)\end{array}$ \\
\hline LAGGED GROWTH & $\begin{array}{l}-0.027 * * * \\
(0.00)\end{array}$ & $\begin{array}{l}-0.022 * * \\
(0.03)\end{array}$ & $\begin{array}{c}-0.003 \\
(0.82)\end{array}$ \\
\hline LAGGED POLITY & $\begin{array}{l}-0.115^{* * * *} \\
(0.00)\end{array}$ & $\begin{array}{l}-0.080 * * \\
(0.02)\end{array}$ & $\begin{array}{l}-0.190 * * * \\
(0.00)\end{array}$ \\
\hline PREVIOUS TRANSITIONS & $\begin{array}{l}0.283 * * * \\
(0.00)\end{array}$ & $\begin{array}{l}0.246^{* * * *} \\
(0.00)\end{array}$ & $\begin{array}{l}0.337 * * * \\
(0.00)\end{array}$ \\
\hline YEAR & $\begin{array}{l}0.019 * * \\
(0.03)\end{array}$ & $\begin{array}{l}0.078^{* *} \\
(0.02)\end{array}$ & $\begin{array}{r}0.007 \\
(0.77)\end{array}$ \\
\hline AGE & $\begin{array}{l}-0.074 * * \\
(0.01)\end{array}$ & $\begin{array}{l}-0.098 * * * \\
(0.01)\end{array}$ & $\begin{array}{c}-0.065 \\
(0.19)\end{array}$ \\
\hline AGE SQUARED & $\begin{array}{r}0.001 \\
(0.21)\end{array}$ & $\begin{array}{c}0.002 \\
(0.12)\end{array}$ & $\begin{array}{r}0.001 \\
(0.67)\end{array}$ \\
\hline AGE CUBED & $\begin{array}{r}-0.000 \\
(0.47)\end{array}$ & $\begin{array}{c}-0.000 \\
(0.38)\end{array}$ & $\begin{array}{r}-0.000 \\
(0.89)\end{array}$ \\
\hline Constant & $\begin{array}{c}-42.512 * * \\
(0.02)\end{array}$ & $\begin{array}{c}-159.775^{* *} \\
(0.02)\end{array}$ & $\begin{array}{r}-18.972 \\
(0.70)\end{array}$ \\
\hline Observations & 3,488 & 1,645 & 1,666 \\
\hline Countries & 129 & 107 & 117 \\
\hline
\end{tabular}

Notes: Dependent variable equals 1 if the Polity 2 score changed by three or more points in a positive direction from $t-1$ to $t$. Logit analysis with robust standard errors clustered on recipient; $p$-values are in parentheses. $* p<.10 ; * * p<.05$; $* * * p<.01$.

The coefficient on aid is negative but not significant for the full period (Model 1). As Models 2 and 3 show, this masks heterogeneity across periods. During the Cold War, more aid is associated with a decreased likelihood that a country experiences democratic change. The same is not true in the post-Cold War, where the coefficient on aid is positive but not significant. A Wald test for equality of the coefficients for aid between Models 2 and 3 suggest that they are not equal $(p<0.02)$. This provides strong support for H1A: the relationship between aid and the likelihood of democratic

55. The analysis excludes the transition years of 1991 and 1992.

56. A single model for 1973-2010 with an indicator for the Cold War (equal to one prior to 1991) entered independently and interacted separately with aid and oil revenue shows the same pattern observed in Table 1; see online appendix. The subsamples are shown for ease of exposition and because of difficulty interpreting interaction terms in nonlinear models. See Ai and Norton 2003; and Greene 2010. 
change varies across periods as predicted. This is consistent with changes over time in strategic importance and donor preferences, and the ability of donors to alter the composition of aid in response. If the period is further restricted to the post-2001 "war on terror" period (not shown), the coefficient on aid is $0.399(p=0.04))^{57}$

To further probe the likelihood that a change in the composition of aid drives these differences over time, H1B examines the relationship between oil revenue and democratic change. The coefficients on oil revenue in Table 1 show no evidence that oil has become less likely to impede change over time in these countries. The coefficient is negative across regressions and increases in magnitude from the Cold War to postCold War, although the null of equality cannot be rejected $(p=0.35)$. Further evidence of the difference between aid and oil is the significant difference between the coefficient values for these variables in the post-Cold War period $(p=0.04) .58$

The empirical structure is designed to decrease the chance of reverse causation, which could hold with the lags specified only if democratization causes aid before the democratization occurs. Even if this occurs, given the comparative nature of the hypotheses, any explanation based on reverse causality would need to account for variation across periods in this relationship. Although not impossible, this is likely implausible. Furthermore, explanations consistent with the model can incorporate reverse causality; I discuss this in the online appendix.

Neither the model nor the empirical results should be taken as evidence that aid can cause democratization. The argument is that donors, when it fits their needs and preferences, allocate aid in a manner that does not prevent democratic change. This is not the same as claiming that they know how to bring about change. The analysis here captures a different question than that asked by studies examining whether aid targeted for democracy promotion actually promotes democratization. ${ }^{59}$ Instead, the present analysis engages with studies examining the relationship between the total amount of aid and the likelihood of political change in recipients.

In developing countries foreign aid — which comes from a donor-exhibits a change over time that is not evident for revenue from oil, providing strong support for H1A and H1B. There is no evidence that foreign aid in the post-Cold War period inhibits democratic change. Oil revenue, on the other hand, is associated with a decreased likelihood of change even after the end of the Cold War.

57. See online appendix.

58. It would be a mistake to draw lessons from this analysis for the debate regarding the relationship between oil revenue and democratization. For example, see Ross 2012; and Haber and Menaldo 2011. This analysis is restricted to aid recipient countries because aid is the primary variable of interest. Within this group of countries, it is reasonable to compare the coefficients of aid with those on oil. However, eligibility as an aid recipient is restricted by income (high-income countries are ineligible based on OECD reporting criteria). This makes it inappropriate to draw lessons for the overall relationship between oil revenue and democratic change from this group of countries; oil has made some countries rich and therefore ineligible for official development assistance.

59. For example, Finkel, Perez-Linan, and Seligson 2007. 
Country fixed effects. The results in Table 1 cannot distinguish between crosscountry and within-country variation. To mitigate concerns that the results are driven by unmeasured country-specific attributes, country fixed effects can be included. Unfortunately, there is a significant loss of observations and countries due to separation when fixed effects are included in a model with a binary dependent variable, such as those in Table $1 .{ }^{60}$ Table 2 reports alternate models that use nonbinary measures of democratic change for the dependent variable and include country fixed effects.

Results reported in Table 2 show that the pattern observed in Table 1 on the coefficient for foreign aid over time is robust to the inclusion of recipient country fixed effects and to the use of alternate measures of political change for the dependent variable. Models 4 and 5 use the change from $t-1$ to $t$ in a country's Polity 2 score as the dependent variable. Note that this change can be either positive or negative. For Models 6 and 7, the dependent variable is measured as the change in a country's average on the Freedom House measures of political rights and civil liberties for a given year, inverted so that higher values are more democratic. ${ }^{61}$ Using the change in Polity or Freedom House from $t-1$ to $t$ as a measure of political change and including country fixed effects, there is a negative, significant coefficient on aid in the Cold War and a positive, insignificant coefficient in the post-Cold War-the same pattern observed in Table $1 .{ }^{62}$

The coefficient on oil revenue, although negative in all models, is significant in only one of the four. It is not surprising that the inclusion of country fixed effects diminishes the significance of oil revenue. Many leaders in oil-rich countries have long time horizons and may be able to smooth spending over short fluctuations in oil prices so that yearly fluctuations in oil revenue have little impact unless they are particularly severe. The variation is more likely between countries that have significant oil revenue and those that do not, rather than within oil-rich countries.

Robustness. In addition to the inclusion of fixed effects, the use of an alternate dependent variable from Freedom House, and revisiting previous research, other robustness checks were performed. ${ }^{63}$ The results are almost identical to those reported in Table 1 if a rare events logit is estimated. Additionally, using as the dependent variable an indicator for a five-point or more shift in Polity2 (rather than the three-point shift earlier), or for a two-or-more-, four-or-more-, or six-or-morepoint shift, the pattern of a negative, significant coefficient on aid in the Cold

60. See Beck and Katz 2001. Including country fixed effects in Models 1 to 3 of Table 1 would decrease the number of observations and countries significantly (see online appendix). Separation is further discussed below in the context of the analysis in Ahmed 2012.

61. Freedom House 2011.

62. An alternative would be to estimate the models with the binary dependent variable in Table 1 using ordinary least squares (OLS) with country fixed effects, Beck 2011. This approach yields the same pattern; see online appendix.

63. All results from alternative models are in the online appendix. 
TABLE 2. Models including country fixed effects

\begin{tabular}{|c|c|c|c|c|}
\hline & \multicolumn{2}{|c|}{ Change in Polity2 } & \multicolumn{2}{|c|}{ Change in Freedom House } \\
\hline & $\begin{array}{l}\text { Cold War } \\
\text { Model } 4\end{array}$ & $\begin{array}{l}\text { Post-Cold War } \\
\text { Model } 5\end{array}$ & $\begin{array}{l}\text { Cold War } \\
\text { Model } 6\end{array}$ & $\begin{array}{l}\text { Post-Cold War } \\
\text { Model } 7\end{array}$ \\
\hline LN AID PER CAPITA (lag 2) & $\begin{array}{l}-0.205^{* *} \\
(0.02)\end{array}$ & $\begin{array}{l}0.082 \\
(0.14)\end{array}$ & $\begin{array}{c}-0.042 * \\
(0.09)\end{array}$ & $\begin{array}{l}0.001 \\
(0.94)\end{array}$ \\
\hline LN OIL REV PER CAPITA (lag 2) & $\begin{array}{c}-0.116 \\
(0.22)\end{array}$ & $\begin{array}{c}-0.039 \\
(0.57)\end{array}$ & $\begin{array}{c}-0.002 \\
(0.95)\end{array}$ & $\begin{array}{c}-0.034^{*} \\
(0.05)\end{array}$ \\
\hline LN INCOME (lag 2) & $\begin{array}{l}0.260 \\
(0.46)\end{array}$ & $\begin{array}{c}-0.032 \\
(0.89)\end{array}$ & $\begin{array}{c}-0.002 \\
(0.98)\end{array}$ & $\begin{array}{c}0.042 \\
(0.49)\end{array}$ \\
\hline LAGGED GROWTH & $\begin{array}{r}-0.005 \\
(0.30)\end{array}$ & $\begin{array}{c}-0.003 \\
(0.62)\end{array}$ & $\begin{array}{c}0.001 \\
(0.66)\end{array}$ & $\begin{array}{l}0.000 \\
(0.94)\end{array}$ \\
\hline LAGGED POLITY & $\begin{array}{l}-0.208^{* * * *} \\
(0.00)\end{array}$ & $\begin{array}{l}-0.272 * * * \\
(0.00)\end{array}$ & & \\
\hline LAGGED FREEDOM HOUSE & & & $\begin{array}{l}-0.264 * * * \\
(0.00)\end{array}$ & $\begin{array}{l}-0.265^{* * * *} \\
(0.00)\end{array}$ \\
\hline YEAR & $\begin{array}{l}0.068 * * * \\
(0.00)\end{array}$ & $\begin{array}{l}0.030 * * * \\
(0.01)\end{array}$ & $\begin{array}{l}0.015 * * * \\
(0.00)\end{array}$ & $\begin{array}{l}0.009^{* * * *} \\
(0.01)\end{array}$ \\
\hline Constant & $\begin{array}{c}-136.195^{* * *} \\
(0.00)\end{array}$ & $\begin{array}{l}-60.063^{* * *} * \\
(0.01)\end{array}$ & $\begin{array}{l}-28.182 * * * \\
(0.00)\end{array}$ & $\begin{array}{l}-17.046^{* * * *} \\
(0.01)\end{array}$ \\
\hline Observations & 1,884 & 2,277 & 1,788 & 2,415 \\
\hline Countries & 113 & 138 & 119 & 144 \\
\hline Country fixed effects & yes & yes & yes & yes \\
\hline
\end{tabular}

Notes: Dependent variable is the change in Polity2 score or in the (inverted) Freedom House average from $t$ - 1 to $t$. Robust standard errors are clustered on recipient; $p$-values are in parentheses. $* p<.10 ; * * p<.05 ; * * * p<.01$.

War and an insignificant positive coefficient in the post-Cold War remains. Models 2 and 3 are reestimated including a control for the recipient country's population size; once again a change consistent with H1A is noted across time for foreign aid, whereas revenue from oil remains negative in both periods, providing support for H1B.

\section{Strategically Important Recipients}

Tables 1 and 2 show a change, on average, in the relationship between aid and the likelihood of democratic change over time. However H2A suggests that in strategically important recipients, the government may be able to obtain a high degree of control over aid resources even in the post-Cold War period. To test for differences in the relationship between aid and democratic change across recipients, Table 3 introduces an indicator variable that equals 1 if a country is one of the top five recipients of US military aid in a given year (which is not a component of the foreign aid examined here) and its interaction with AID, both lagged two years. This is meant to capture only the most strategically important countries, so is restrictive by design. ${ }^{64}$ 
TABLE 3. Aid and democratic change for heterogeneous recipients

\begin{tabular}{|c|c|c|c|c|}
\hline & $\begin{array}{l}\text { Cold War } \\
\text { Model } 8\end{array}$ & $\begin{array}{l}\text { Post-Cold War } \\
\text { Model } 9\end{array}$ & $\begin{array}{l}\text { Cold War } \\
\text { Model } 10\end{array}$ & $\begin{array}{l}\text { Post-Cold War } \\
\text { Model } 11\end{array}$ \\
\hline LN AID PER CAPITA (lag 2) & $\begin{array}{l}-0.207^{* *} \\
(0.03)\end{array}$ & $\begin{array}{c}0.222 \\
(0.16)\end{array}$ & $\begin{array}{l}-0.214^{* *} \\
(0.03)\end{array}$ & $\begin{array}{c}0.221 \\
(0.16)\end{array}$ \\
\hline TOP 5 US MILITARY ( $\operatorname{lag} 2$ ) & $\begin{array}{l}3.008^{* *} \\
(0.03)\end{array}$ & $\begin{array}{l}8.089 * * * \\
(0.00)\end{array}$ & $\begin{array}{l}3.574^{*} \\
(0.06)\end{array}$ & $\begin{array}{l}7.183^{* *} \\
(0.05)\end{array}$ \\
\hline TOP $5 *$ AID (lag 2) & $\begin{array}{c}-0.699 \\
(0.14)\end{array}$ & $\begin{array}{l}-2.089 * * * \\
(0.00)\end{array}$ & $\begin{array}{r}-1.057 \\
(0.14)\end{array}$ & $\begin{array}{l}-1.968^{* *} \\
(0.02)\end{array}$ \\
\hline LN OIL REV PER CAPITA (lag 2) & $\begin{array}{c}-0.039 \\
(0.48)\end{array}$ & $\begin{array}{l}-0.151^{* *} \\
(0.02)\end{array}$ & $\begin{array}{c}-0.056 \\
(0.31)\end{array}$ & $\begin{array}{l}-0.152^{* * *} \\
(0.02)\end{array}$ \\
\hline тоР $5 *$ OLL (lag 2) & & & $\begin{array}{c}0.329 \\
(0.16)\end{array}$ & $\begin{array}{r}0.107 \\
(0.66)\end{array}$ \\
\hline LN INCOME (lag 2) & $\begin{array}{l}0.330 * * \\
(0.02)\end{array}$ & $\begin{array}{r}0.131 \\
(0.52)\end{array}$ & $\begin{array}{l}0.360 * * * \\
(0.01)\end{array}$ & $\begin{array}{r}0.131 \\
(0.52)\end{array}$ \\
\hline LAGGED GROWTH & $\begin{array}{l}-0.027 * * \\
(0.01)\end{array}$ & $\begin{array}{c}-0.002 \\
(0.90)\end{array}$ & $\begin{array}{l}-0.026^{* *} \\
(0.02)\end{array}$ & $\begin{array}{c}-0.002 \\
(0.90)\end{array}$ \\
\hline LAGGED POLITY & $\begin{array}{l}-0.072 * * \\
(0.04)\end{array}$ & $\begin{array}{l}-0.201 * * * \\
(0.00)\end{array}$ & $\begin{array}{l}-0.080^{* *} \\
(0.03)\end{array}$ & $\begin{array}{l}-0.201 * * * \\
(0.00)\end{array}$ \\
\hline PREVIOUS TRANSITIONS & $\begin{array}{l}0.211^{* *} \\
(0.02)\end{array}$ & $\begin{array}{l}0.341 * * * \\
(0.00)\end{array}$ & $\begin{array}{l}0.222^{* *} \\
(0.01)\end{array}$ & $\begin{array}{l}0.343 * * * \\
(0.00)\end{array}$ \\
\hline YEAR & $\begin{array}{l}0.074 * * \\
(0.03)\end{array}$ & $\begin{array}{c}0.002 \\
(0.93)\end{array}$ & $\begin{array}{l}0.073 * * \\
(0.04)\end{array}$ & $\begin{array}{r}0.002 \\
(0.94)\end{array}$ \\
\hline AGE & $\begin{array}{l}-0.092^{* *} \\
(0.01)\end{array}$ & $\begin{array}{c}-0.059 \\
(0.24)\end{array}$ & $\begin{array}{l}-0.093^{* *} \\
(0.01)\end{array}$ & $\begin{array}{c}-0.058 \\
(0.25)\end{array}$ \\
\hline AGE SQUARED & $\begin{array}{c}0.002 \\
(0.14)\end{array}$ & $\begin{array}{r}0.001 \\
(0.73)\end{array}$ & $\begin{array}{r}0.002 \\
(0.14)\end{array}$ & $\begin{array}{r}0.001 \\
(0.75)\end{array}$ \\
\hline AGE CUBED & $\begin{array}{c}-0.000 \\
(0.39)\end{array}$ & $\begin{array}{c}-0.000 \\
(0.93)\end{array}$ & $\begin{array}{c}-0.000 \\
(0.40)\end{array}$ & $\begin{array}{c}-0.000 \\
(0.94)\end{array}$ \\
\hline Constant & $\begin{array}{c}-150.419^{* *} \\
(0.03)\end{array}$ & $\begin{array}{r}-8.921 \\
(0.85)\end{array}$ & $\begin{array}{c}-148.690 * * \\
(0.03)\end{array}$ & $\begin{array}{c}-8.503 \\
(0.86)\end{array}$ \\
\hline Observations & 1,645 & 1,666 & 1,645 & 1,666 \\
\hline Countries & 107 & 117 & 107 & 117 \\
\hline
\end{tabular}

Notes: Dependent variable equals 1 if the Polity 2 score changed by three or more points in a positive direction from $t-1$ to $t$. Logit analysis with robust standard errors clustered on recipient; $p$-values are in parentheses. $* p<.10 ; * * p<.05$; $* * * p<.01$.

US military assistance may not be the best proxy of strategic importance for all democratic donors. However, the United States is the largest bilateral aid donor and has significant influence with the major multilateral donors. It is important that any proxy for strategic importance for overall levels of aid pick up strategic importance to the United States. Additionally, for the most strategic cases, many North Atlantic Treaty Organization (NATO) donors increase aid as US military aid increases, suggesting that they are responding to the strategic importance of these countries. ${ }^{65}$ The use of US military assistance is not meant to imply that it is the only

65. Examples of this are large amounts of aid from multiple bilateral donors to Egypt, Pakistan, Jordan, and the Philippines in the 1980s as well as to Iraq and Afghanistan in recent years. See also Kersting and Kilby 2014. 
possible measure of strategic importance. Rather, it is one possible way to measure whether strategic importance - which may arise for various reasons-has an impact on the relationship between foreign aid and democratic change.

Table 3 explores whether the variation over time shown by the results applies regardless of a recipient government's strategic position, or if strategically important recipient governments are better able to manipulate aid for their advantage. The results suggest that the latter is more likely true. Models 8 and 9 report results for the Cold War and post-Cold War, respectively. The coefficients for the LN AID PER CAPITA term capture the relationship between aid and the likelihood of democratic change in recipients not classified as strategically important, and show the same pattern over time as that observed in Table 1. The coefficients on the interaction term between aid per capita and strategic importance, TOP $5^{*}$ AID, are negative in both models and significant in the post-Cold War period. The results are consistent with strategically important recipient governments using aid to prevent democratic change even in the post-Cold War period. The larger-magnitude coefficient and increased significance for the variable TOP $5^{*}$ AID in the post-Cold War show donors compensating for the decline in average effect in these particularly important recipients and highlight an increased divide between the two recipient types. Models 10 and 11 are analogous to Models 8 and 9, but with the addition of an interaction term тор $5 *$ OIL. That interaction is not significant and including it does not change the pattern for aid. These results present strong support for H2A and H2B, showing that aid, but not oil, has a different relationship with the likelihood of democratic change in strategically important states. ${ }^{66}$

\section{Comparison with Previous Work}

These findings challenge the results of several recent studies that conclude that aid inhibits political change in recipients. This section revisits analyses by Morrison, ${ }^{67}$ Bueno de Mesquita and Smith, ${ }^{68}$ and Ahmed ${ }^{69}$ to better understand the underlying factors leading to different results. ${ }^{70}$ There are multiple potential reasons for these differences. From a theoretical perspective, none of these studies tests for differences in the aid-democratic change relationship over time. From an empirical point of view, none of these studies is identical to the present analysis or to each other in terms of time, countries, variables, and methods.

66. A similar pattern is observed if the top ten recipients of military aid, rather than the top five, are designated as important.

67. Morrison 2009.

68. Bueno de Mesquita and Smith 2010.

69. Ahmed 2012.

70. E-mail communication with the authors confirms that replication files for Djankov, Montalvo, and Reynal-Querol 2008 are unavailable. 
TABLE 4. Analysis of Morrison 2009, Table 3, Model 1

\begin{tabular}{lccc}
\hline & $\begin{array}{c}\text { Replication } \\
(1)\end{array}$ & $\begin{array}{c}\text { Cold War } \\
(2)\end{array}$ & $\begin{array}{c}\text { Post-Cold War } \\
(3)\end{array}$ \\
\hline GRANTS PER CAPITA $(t-1)$ & $-0.0175^{* *}$ & $-0.0664^{* *}$ & -0.0049 \\
& $(0.008)$ & $(0.031)$ & $(0.011)$ \\
SOE REV PER CAPITA $(t-1)$ & $-0.0016^{* *}$ & -0.0009 & $(0.001)$ \\
& $(0.001)$ & $-0.0021^{* *}$ & $(0.007)$ \\
OTHER NONTAX REV PER CAPITA $(t-1)$ & $-0.0012^{* *}$ & $(0.001)$ & $(0.0015$ \\
Observations & $(0.001)$ & 747 & 419 \\
Countries & 1,307 & 77 & 73 \\
\end{tabular}

Notes: Dependent variable equals 1 if there is a three-point change in Polity in either direction, 0 otherwise. Logit analysis with robust standard errors clustered by country in parentheses. Column (1) replicates Table 3, Model 1 , from Morrison 2009. Columns (2) and (3) use the same data but for pre-1989 and post-1991, respectively. ${ }^{*} p<.10$; $* * p<.05 ; * * * p<.01$.

\section{Morrison}

Morrison argues that multiple forms of "nontax revenue," including foreign aid and revenue from state-owned oil enterprises, have a similar effect of decreasing the likelihood of regime transition. ${ }^{71}$ As a result of this, he concludes that they can be aggregated into a single category of nontax revenue for empirical analysis. The first column of Table 4 exactly replicates the results from Table 3, Model 1, of that study, with robust standard errors in parentheses. ${ }^{72}$ The dependent variable is an indicator that takes the value of 1 if a country experienced a three-point change in its Polity score. This is similar to the measure used in Table 1 earlier, except that in Morrison's analysis the change in Polity can be either positive or negative. The time period is 1973-2001. The variable GRANTS PER CAPITA is used as the measure of foreign aid. A central claim of the article is that "the particular source of nontax revenue - state-owned enterprises, aid, or other sources — does not make a difference: they all act similarly with regard to regime stability and the causal mechanisms." 73 Model 1 is presented as evidence of this: "As shown in Model 1 of Table 3, the coefficients on all three nontax revenue components are negative and significant. ... This result is important in its own right, as it demonstrates that foreign aid, state-owned enterprise revenue, and other kinds of nontax revenue-including borrowing — have similar effects." 74

Column (2) presents results using the same data and model, but restricting the time period to pre-1989; column (3) does the same for the post-1991 period. As the table shows, the coefficient on GRANTS PER CAPITA is significant only in the earlier period

71. All references to Morrison in this section refer to Morrison 2009.

72. Relevant variables shown; see online appendix for results including all variables.

73. Morrison 2009, 109.

74. Ibid., 119-20. 
(for the post-Cold War, $p=0.66$ ). A Wald test on the coefficients for GRANTS PER CAPITA in columns (2) and (3) suggests they are unlikely to be equal $(p=0.07)$, indicating that the decrease in magnitude from the Cold War to the post-Cold War is significant. This sharply contrasts with the pattern observed for the coefficient on revenue from state-owned enterprises (SOE), which increases in magnitude over time and is significant only in the post-1991 period (for the Cold War, $p=0.52$ ). ${ }^{75}$ The evidence is consistent with both H1A and H1B: there is a difference in the coefficient on aid across time periods and no evidence that the relationship of oil (included in SOE revenue) with regime change follows the same pattern.

Differences are not only due to the failure to differentiate across time. A closer examination of the data used by Morrison suggests that they may not be well suited for testing hypotheses regarding foreign aid. The variable GRANTS PER CAPITA, used as a measure of aid, contains large values of grants for OECD countries (which are not generally considered aid eligible under international definitions) and excludes in-kind aid that is given to developing countries (which is usually included in measures of aid). This creates a sizeable difference between this variable and standard measures of foreign aid. Additionally, about two-thirds of the possible observations are dropped from the analysis in a nonrandom way because of issues of missing data. ${ }^{76}$ Even given these issues, the analysis reported in Table 4 shows no evidence of a significant negative relationship between the variable used to measure aid and the likelihood of regime change in the post-Cold War period. Instead, disaggregating the data into the Cold War and post-Cold War periods shows results consistent with those hypothesized earlier.

\section{Implications Beyond Democratic Change}

The studies by Bueno de Mesquita and Smith ${ }^{77}$ and $\mathrm{Ahmed}^{78}$ focus on survival of individual leaders or governments, respectively, rather than the likelihood of democratic change. The model I developed allows donor preferences regarding democratization to vary across time. It is not clear that the donor preference argument extends exactly to leader or government survival. Democratic change can occur without a change in leadership, and changes in government or leadership do not necessarily correspond with democratic change: many involve the transfer of power from one authoritarian ruler to another, ${ }^{79}$ or the election of a new leader/party within a democracy.

Despite the difficulties in specifying an exact parallel with the model, one implication from the model should apply: if aid was ever likely to prop up authoritarian leaders, it should not do so on average in the post-Cold War period. The studies

75. Interaction terms with Cold War can be used instead of the subperiod analysis shown here and the conclusions hold; see online appendix.

76. These issues are substantive and discussed more fully in the online appendix.

77. Bueno de Mesquita and Smith 2010.

78. Ahmed 2012.

79. Geddes, Wright, and Frantz 2014. 
by Ahmed and Bueno de Mesquita and Smith claim that aid reduces the likelihood of government or leader turnover in authoritarian regimes. If this claim withstands scrutiny for the post-Cold War period, it poses a challenge to my main argument.

TABLE 5. Reproduced from Bueno de Mesquita and Smith 2010, Tables 1 and 2

\begin{tabular}{|c|c|c|c|}
\hline & Independent variable & Coefficient & $p$-value \\
\hline Model 2 & NONTAX REVENUE (\% GDP) & -0.0601 & 0.024 \\
\hline Model 2 & W*NONTAX REVENUE & 0.0808 & 0.046 \\
\hline Model 3 & OIL (EXPORTS as \% GDP) & -0.0201 & 0.051 \\
\hline Model 3 & $\mathrm{w}^{*} \mathrm{OIL}$ & 0.0141 & 0.380 \\
\hline Model 4 & AID ( $\%$ GDP $)$ & -0.00427 & 0.872 \\
\hline Model 4 & $\mathrm{~W} * \mathrm{AID}$ & -0.0135 & 0.733 \\
\hline
\end{tabular}

Notes: Coefficients are reproduced from Bueno de Mesquita and Smith 2010, Table 1: LEADER SURVIVAL (parametric Weibull model); $p$-values added using data from the replication files.

\begin{tabular}{|c|c|c|c|}
\hline & Independent variable & Coefficient & $p$-value \\
\hline Model 7 & OIL $*$ MASS & -0.00329 & 0.000 \\
\hline Model 7 & $\mathrm{~W} * \mathrm{OIL}^{*} * \Delta$ MASS & 0.00481 & 0.002 \\
\hline Model 8 & AID* $\Delta$ MASS & 0.00148 & 0.573 \\
\hline Model 8 & $\mathrm{~W} * \mathrm{AID}^{*} \Delta \mathrm{MASS}$ & -0.00178 & 0.658 \\
\hline
\end{tabular}

Notes: Coefficients are reproduced from Bueno de Mesquita and Smith 2010, Table 2: FUTURE COALITION SIZE, w (3 years); $p$-values added using data from the replication files.

Bueno de Mesquita and Smith. Bueno de Mesquita and Smith argue that governments are better able to dissipate revolutionary threats when they have "access to abundant, essentially labor-free resources (hereafter free resources) such as natural resource rents or foreign aid." 80 A reexamination of the analysis calls into question whether this claim holds in any period for foreign aid. Their central results on leader survival are reported in Models 2 to 4 of Table 1 of their article; the relevant coefficients are reproduced here without alteration in Table 5, with the addition of the relevant $p$-values. ${ }^{81}$ Model 2 uses the aggregate measure of nontax revenue employed by Morrison; 82 the coefficients for nontax revenue (\% GDP) and the interaction of nontax revenue with winning coalition size (w) from their Table 1, Model 2, are shown in Table 5. Models 3 and 4 drop the nontax revenue variable and instead include variables for oil exports as a percent of gross domestic product (GDP) (Models 3 and 4) and aid as a percent of GDP (Model 4). ${ }^{83}$ Data

80. Bueno de Mesquita and Smith 2010, 937.

81. The coding of leader survival is based on Goemans, Gleditsch, and Chiozza 2009.

82. Morrison 2009.

83. For a discussion of problems associated with including gross domestic product (GDP) in the denominator for such analyses, see Ross 2008. 
on foreign aid and oil for Models 3 and 4 are from the World Bank. The time period is 1972-2000 in Model 2 and 1962-2004 in Models 3 and 4.

Based on these results, Bueno de Mesquita and Smith claim that "There is a negative coefficient on the free resources variable, be it measured as nontax revenue, Oil, or Aid. This indicates that if small-coalition leaders gain access to additional free resources then their risk of deposition is reduced." ${ }^{4}$ Although they do note afterward that the "estimates on the free resource variables" in Model 4 are "insignificant," 85 there is no evidence that "each of these models reveals a similar pattern" as they claim. ${ }^{86}$ Although the coefficients on nontax revenue in Model 2 and oil in Model 3 are negative and significant, the negative coefficient on aid in Model 4 is much smaller and does not approach statistical significance $(p=0.87)$. Additionally, the article claims that the impact of "free resources" varies with coalition size, w: evidence for this is the positive and significant coefficient on the interaction of w with nontax revenue in Model 2. There is no such pattern for the coefficient on the corresponding term for $\mathrm{w}^{*} \mathrm{AID}$ in Model 4: the coefficient flips signs and is not significant $(p=0.73)$. The study claims that "incumbents are most likely to survive when they are beholden to only a small coalition of supporters and when they have access to resources—-such as oil and aid - that do not require significant economic participation by the citizens." 87 There is no evidence that this statement applies to foreign aid.

Although it would be useful to examine the Cold War and post-Cold War periods separately, empirical difficulties arise when the underlying data are examined. The observations for Table 1 from Bueno de Mesquita and Smith are structured at the leaderyear level, whereas the values for aid, oil, w, and other independent variables are at the country-year level. This means that the same value for each independent variable can apply to multiple leaders in the same year, making interpretation difficult. For instance, Haiti had three leaders in 1990 and each has a separate entry in the data set. However, each entry has the same value for aid, income, w, and other variables. This is particularly problematic for $\mathrm{w}$, which is coded at the end of the calendar year but applies that value to leaders from any portion of the same calendar year. ${ }^{88}$ When the analysis from Bueno de Mesquita and Smith's Table 1 is performed separately for the Cold War and post-Cold War periods (not shown), the key coefficients relating to foreign aid are not significant in either period. However, given the structure of the underlying data it is not clear that much weight should be placed on this result.

Bueno de Mesquita and Smith also analyze the relationship between "free resources" and institutional change- a change in the size of the winning coalition-in Table 2, Models 6 to 9 of their article. Once again there is no evidence that aid has the claimed effect, or that aid and oil revenue operate in a similar fashion. The bottom half of Table 5 shows results on the key terms from Models 7 and 8 reproduced

84. Bueno de Mesquita and Smith 2010, 943.

85. Ibid., 944.

86. Ibid., 943 .

87. Ibid., 936.

88. See online appendix for further discussion. 
exactly from the article: in Model 7 oil is the only "nontax" resource included; Model 8 includes measures of both oil and aid. Each model also includes controls and several interaction terms including oil or aid. The authors wish to analyze "how revolutionary threats and free resources interact to affect institutional change over three years." 89 Revolutionary threats are measured as the change in the level of mass political movements over the previous three years ( $\triangle$ MASS). The expectation is that mass political movements cause an increase in the size of the winning coalition (measured three years in the future), but that nontax revenue will negate this democratizing effect of mass movements. Hence, the study hypothesizes a negative coefficient on interactions between forms of nontax revenue (for example, oll and/or AID) and $\triangle$ MAss. However, this is expected to operate only in countries that start out with a small winning coalition (w); if the country is already democratic ( $w$ is large) then nontax revenue will not have this negative effect. Therefore, a further hypothesis is for a positive coefficient on the triple interaction between $\mathrm{w}$, OIL or AID, and $\triangle$ MASS.

When interpreting the coefficient on the variable olL $* \Delta$ MASS in Model 7, the authors write that "the negative coefficient on the interaction variable, $\triangle \mathrm{MASS} * \mathrm{OLL}$, indicates that when a leader has access to free resources, increases in mass political movements are likely to result in contractions rather than expansions of the winning coalition." 90 They note that this result only holds in small coalition systems: the positive coefficient on the term $\mathrm{w}^{*} \mathrm{OLL}^{*} \Delta$ MASS shows that as coalition size increases the negative effect disappears. This finding actually applies to revenue from oil resources only, not to foreign aid. Table 5 shows the coefficients on the relevant interaction terms for aid in Model 8: $\mathrm{AID}^{*} \Delta \mathrm{MASS}$ and $\mathrm{w}^{*} \mathrm{AID} * \Delta \mathrm{MASS}$. In each case the coefficients are insignificant and of opposite sign to the corresponding interactions for oil. This point is not noted, however. Instead, the article refers to the "pernicious effects of free resources in retarding democratization." 11

In their abstract Bueno de Mesquita and Smith claim that "tests of leader survival indicate that revolutionary threats increase the likelihood of deposition for nondemocratic leaders. Leaders with access to resources such as foreign aid or natural resource rents are best equipped to survive these threats and avoid the occurrence of these threats in the first place." 92 Revisiting the results suggests that this claim is unwarranted with respect to foreign aid.

Ahmed. The argument in Ahmed differs from that of Bueno de Mesquita and Smith by making the case that aid and remittances, rather than aid and oil revenue, have a similar relationship with the likelihood of government survival. Ahmed examines the period 1975-2004. The preferred dependent variable is a dichotomous measure that equals 1 if there is government turnover according to the measure of years in office included in the Database of Political Institutions. ${ }^{93}$ Based on the statistical results, the

89. Bueno de Mesquita and Smith 2010, 944.

90. Ibid.

91. Ibid., 946.

92. Ibid., 936.

93. Beck et al., 2001. 
article claims that aid and remittances should be combined into a single measure when evaluating their impact on the likelihood of government turnover.

Model 3 in Table 3 of Ahmed's article is the only one that includes aid and remittances separately. The article hypothesizes that aid and remittances will have a negative effect on the likelihood of government turnover in authoritarian regimes. Thus, the interest is in the combination of the coefficient on aid or remittances and the coefficient on its interaction with authoritarianism (measured as the inverse of the Polity2 scale, with higher scores representing more authoritarian regimes). As the article notes, none of these coefficients are significant in Model 3. Despite this, it is determined that the coefficients on the interaction terms AUTOCRACY*AID and AUTOCRACY* REMITTANCES are "not different" and that this justifies aggregation of aid and remittances in all other models. The replication files show that a Wald test for equality between the two coefficients has a $p$-value of 0.462 : whereas the null of equality cannot be rejected, there is no evidence that the two coefficients are, in fact, equal.

There are issues with the model and underlying data that must be addressed before further analysis. All models in Table 3 of Ahmed's article lose large numbers of observations due to separation induced by including country, year, and duration fixed effects in the probit models. This is similar to selecting on the dependent variable-countries, years, or duration spells that do not experience change are dropped from the analysis and have no impact on the estimated coefficients. ${ }^{94}$ In Model 3 of Table 3, separation results in the loss of 664 observations, or 29 percent of the data; it also reduces the country coverage from 120 to 97 because countries that never experience a change are dropped. ${ }^{95}$

It is possible to correct for separation and examine the relationship between aid, remittances, and the likelihood of government turnover using the data from the original article.$^{96}$ However, additional alterations to the original data and methods are required to properly perform this test. The rescaling of the AUTOCRACY measure from the original Polity 2 values to a new (inverted) scale ranging from 0 to 1 (with 1 as the most autocratic) was not done in a linear fashion in the underlying data. The movement from -10 to -9 is associated with a change from 1 to 0.5 (a difference of 0.5), whereas a movement from 9 to 10 is associated with a move from 0.050 to 0.048 (a difference of 0.002). This means that the difference between a -10 and -9 on Polity 2 is more than 200 times the difference between 9 and 10 in the rescaled score. ${ }^{97}$ Instead of relying on this score, a linear scale is created in which each difference of 1 on the original -10 to 10 scale corresponds to a difference of .05 on the

94. This is different from the coefficient estimates usually produced when fixed effects are included: those disregard units (for example, countries) for which an independent variable does not change when calculating the coefficient for that variable; separation drops observations based on lack of variation on the dependent variable. See Beck and Katz 2001; and Carter and Signorino 2010.

95. See online appendix for further discussion of how separation affects results in the original paper.

96. The online appendix shows the results of correcting for separation in Model 3 without further alteration.

97. See online appendix for additional discussion of this and other data issues. 
(inverted) 0 to 1 scale. It is necessary to lag the AUTOCRACY variable given the coding structure of that variable and the dependent variable (government turnover), but it does not appear that this was done in the original analysis. An observation is coded as 1 for turnover if it experienced a turnover that year. However, Polity2on which the autocracy score is based-is coded as of 31 December of the year in which it is reported. Therefore, the AUTOCRACY score should be lagged by one period to ensure that it is the score prior to the turnover that is used, rather than the score resulting from the turnover. Similar concerns arise from the failure to lag aid and remittances, some of which may also accrue after the turnover in a given year.

TABLE 6. Based on the analysis of Ahmed 2012

\begin{tabular}{|c|c|c|c|}
\hline & $\begin{array}{l}\text { Full period } \\
\text { Column } 1\end{array}$ & $\begin{array}{l}\text { Pre-1989 } \\
\text { Column } 2\end{array}$ & $\begin{array}{l}\text { Post-1991 } \\
\text { Column } 3\end{array}$ \\
\hline AUTOCRACY & $\begin{array}{l}-0.995^{* * * *} \\
(0.00)\end{array}$ & $\begin{array}{l}-0.712 * * * \\
(0.00)\end{array}$ & $\begin{array}{c}-1.385^{* * * *} \\
(0.00)\end{array}$ \\
\hline AID (\% GDP) (lagged) & $\begin{array}{c}-0.010 \\
(0.22)\end{array}$ & $\begin{array}{c}0.003 \\
(0.85)\end{array}$ & $\begin{array}{c}-0.020^{*} \\
(0.08)\end{array}$ \\
\hline AUTOCRACY*AID (lagged) & $\begin{array}{r}0.003 \\
(0.83)\end{array}$ & $\begin{array}{c}-0.018 \\
(0.41)\end{array}$ & $\begin{array}{c}0.012 \\
(0.56)\end{array}$ \\
\hline REMITTANCES (\% GDP) (lagged) & $\begin{array}{c}-0.008 \\
(0.78)\end{array}$ & $\begin{array}{c}-0.026 \\
(0.75)\end{array}$ & $\begin{array}{c}0.008 \\
(0.81)\end{array}$ \\
\hline AUTOCRACY*REMITTANCES (lagged) & $\begin{array}{c}-0.038 \\
(0.44)\end{array}$ & $\begin{array}{r}0.007 \\
(0.95)\end{array}$ & $\begin{array}{c}-0.116 \\
(0.27)\end{array}$ \\
\hline Observations & 2,333 & 968 & 1,113 \\
\hline
\end{tabular}

Notes: Probit analysis with robust standard errors clustered on government (not reported); $p$-values are in parentheses. Dependent variable equals 1 if there was a government turnover in year $t$. All independent variables are lagged one period. $* p<.10 ; * * p<.05 ; * * * p<.01$.

The analysis shown in Table 6 employs data drawn from the replication files for Ahmed's article, but uses the rescaled Autocracy score, lags all independent values by one period to ensure they are prior to the turnover, and does not include fixed effects because of the severity of separation induced by their inclusion. To model the hazard without duration fixed effects, duration polynomials based on the replication data are used. ${ }^{98}$ The results in Table 6 show no evidence that aid significantly decreases the likelihood of government turnover in authoritarian regimes in any period: the coefficient on AUTOCRACY*AID is never significant. ${ }^{99}$ Looking at columns (2) and (3), which break out the Cold War and post-Cold War periods, the pattern for aid is consistent with the hypothesis of a change over time, although most coefficients are insignificant. Still, it is worth noting that the coefficient on

98. Relevant variables reported here; see online appendix for full table.

99. This difference from the original article is not a result of removing the fixed effects. When the models in Table 6 are estimated using OLS with country, year, and duration fixed effects the differences between what is found for both aid and remittances and the results from the original article are even more striking. See online appendix. 
AUTOCRACY*AID in the post-Cold War is not only insignificant but also in the opposite direction from that hypothesized by Ahmed. And the negative, significant coefficient on AID in the post-Cold War means that when AUTOCRACY is 0 (Polity 2 score is 10 , the most democratic), aid decreases the likelihood of turnover: so aid may decrease the likelihood of turnover in democracies, but not in autocracies-opposite to Ahmed's predictions. This same pattern for aid is seen if the remittance variables are excluded from the models in Table 6.

These revisited articles claim that foreign aid operates in a similar manner to oil revenue or remittances and that it suppresses political change in authoritarian countries. In no case does a further examination of the results support the conclusion that aid prevents political change in the post-Cold War, or that aid operates in a similar way to other forms of nontax revenue.

\section{Conclusion}

Foreign aid, unlike revenue from state-owned oil enterprises or migrant remittances, comes from a donor country. Donors have preferences that can change over time as the geopolitical climate evolves. The effects of aid will be conditioned by donor priorities and donor-recipient relationships. Failure to account for this omits a key theoretical component from our understanding of foreign aid and its impact in recipient countries.

Policy-makers in developed democracies face difficult choices when operating in nondemocratic countries. Understanding any unintended consequences of their policies on the political situation is important. For aid donors, this is particularly true. A substantial proportion of the world's poor live in nondemocratic countries. Several previous studies conclude that giving aid in these countries reduces the likelihood of democratic change. If decreasing the likelihood of democratization is an unavoidable side effect of giving aid in authoritarian states, then donors will think seriously about these consequences when allocating aid.

The argument developed in this article predicts a more nuanced relationship between aid and democratic change. Furthermore, it suggests that donors are a driving force in determining this relationship. Donors can alter the composition of aid both over time and across recipients, varying the extent to which authoritarian governments can use aid to their own advantage. Empirical tests support the theory: aid to authoritarian recipients need not prevent democratic change. Evidence from the Cold War and from strategically important recipients provides a cautionary tale regarding the ability of aid to have antidemocratic properties. However when a donor's utility is increased by avoiding these consequences, it is able to reallocate aid within authoritarian recipients to prevent antidemocratic effects. This is seen in the post-Cold War period where aid, on average, is not associated with decreased likelihood of democratic change.

Comparing the effects of aid with those of oil revenue provides important insights for understanding the fungibility of aid. Directly ascertaining the level of aid 
fungibility in a generalizable manner has proved elusive. Although fungibility is often asserted in scholarly work, the extent of fungibility remains contested. The findings in this study suggest limits on fungibility, at least in nondemocratic recipients: aid does not have similar effects to oil revenue, which is more widely accepted as a fungible resource. Instead, the results are more consistent with a theory incorporating donor preferences and the heterogeneous nature of aid than with previous theories that assumed aid was a homogenous, fungible resource.

Foreign aid is not oil. It involves a resource transfer from one state to another. As such, the priorities of governments in both states must be considered when developing a theory of the effects of foreign aid. Researchers should resist the temptation to aggregate across types of resources and instead consider the nuances associated with each when studying their impact on outcomes of interest.

\section{Supplementary material}

Supplementary material for this article is available at http://dx.doi.org/10.1017/ S0020818315000296.

\section{References}

Abdih, Yasser, Ralph Chami, and Jihad Dagher. 2012. Remittances and Institutions: Are Remittances a Curse? World Development 40 (4):657-66.

Acemoglu, Daron, Simon Johnson, James A. Robinson, and Pierre Yared. 2008. Income and Democracy. American Economic Review 98 (3):808-42.

Ahmed, Faisal. 2012. The Perils of Unearned Income: Aid, Remittances, and Government Survival. American Political Science Review 106 (1):146-65.

Ai, Chunrong, and Edward C. Norton. 2003. Interaction Terms in Logit and Probit Models. Economics Letters 80:123-29.

Bearce, David H., and Daniel C. Tirone. 2010. Foreign Aid Effectiveness and the Strategic Goals of Donor Governments. Journal of Politics 72 (3):837-51.

Beck, Nathaniel. 2011. Is OLS with a Binary Dependent Variable Really OK? Estimating (Mostly) TSCS Models with Binary Dependent Variables and Fixed Effects. Unpublished manuscript, New York University, New York.

Beck, Nathaniel, and Jonathan N. Katz. 2001. Throwing Out the Baby with the Bath Water: A Comment on Green, Kim, and Yoon. International Organization 55(2):487-95.

Beck, Thorsten, George, Clarke, Alberto Groff, Philip Keefer, and Patrick Walsh. 2001. New Tools in Comparative Political Economy: The Database of Political Institutions. World Bank Economic Review 15(1):165-76.

Bermeo, Sarah Blodgett. 2010. Development and Strategy: Aid Allocation in an Interdependent World. Manuscript, Duke University, Durham, NC.

- 2011. Foreign Aid and Regime Change: A Role for Donor Intent. World Development 39 (11): 2021-31.

Boix, Carles. 2003. Democracy and Redistribution. New York: Cambridge University Press.

Brautigam, Deborah A., and Stephen Knack. 2004. Foreign Aid, Institutions, and Governance in SubSaharan Africa. Economic Development and Cultural Change 52:255-85. 
Bueno de Mesquita, Bruce, and Alastair Smith. 2009. A Political Economy of Aid. International Organization 63 (2):309-40.

- 2010. Leader Survival, Revolutions, and the Nature of Government Finance. American Journal of Political Science 54 (4):936-50.

Carter, David B., and Curtis S., Signorino. 2010. Back to the Future: Modeling Time Dependence in Binary Data. Political Analysis 18(3):271-92.

Carter, David B., and Randall W. Stone. 2015. Democracy and Multilateralism: The Case of Vote Buying in the UN General Assembly. International Organization 69 (1):1-33.

Clemens, Michael, Steven Radelet, Rikhil Bhavnani, and Samuel Bazzi. 2012. Counting Chickens When They Hatch: Timing and the Effects of Aid on Growth. Economic Journal 122 (561):590-17.

Collier, Paul. 2006. Is Aid Oil? An Analysis of Whether Africa Can Absorb More Aid. World Development 34(9):1482-97.

Dietrich, Simone. 2013. Bypass or Engage? Explaining Donor Delivery Tactics in Aid Allocation. International Studies Quarterly 57 (4):698-712.

Djankov, Simeon, Jose G. Montalvo, and Marta Reynal-Querol. 2008. The Curse of Aid. Journal of Economic Growth 13:169-94.

Dunning, Thad. 2004. Conditioning the Effects of Aid: Cold War Politics, Donor Credibility, and Democracy in Africa. International Organization 58:409-23.

- 2008. Crude Democracy: Natural Resource Wealth and Political Regimes. Cambridge, UK: Cambridge University Press.

Easterly, Bill. 2006. Is Foreign Aid Working? Prospect Magazine, 19 October 2006.

Epstein, David L., Robert Bates, Jack Goldstone, Ida Kristensen, and Sharyn O'Halloran. 2006. Democratic Transitions. American Journal of Political Science 50 (3):551-69.

Feyzioglu, Tarhan, Vinaya Swaroop, and Min Zhu. 1998. A Panel Data Analysis of the Fungibility of Foreign Aid. World Bank Economic Review 12 (1):29-58.

Finkel, Steven E., Anibal Perez-Linan, and Mitchell A. Seligson. 2007. The Effects of US Foreign Assistance on Democracy Building, 1990-2003. World Politics 59 (3):404-39.

Freedom House. 2011. Freedom in the World. Available at https://freedomhouse.org/report-types/freedomworld. Accessed 12 March 2011.

Geddes, Barbara, Joseph Wright, and Erica Frantz. 2014. Autocratic Breakdown and Regime Transitions. Perspectives on Politics 12 (2):313-31.

Goemans, Henk E., Kristian Skrede Gleditsch, and Giacomo Chiozza. 2009. Introducing Archigos: A Dataset of Political Leaders. Journal of Peace Research 46 (2):269-83.

Goldberg, Ellis, Eric Mvukiyehe, and Erik Wibbels. 2008. Lessons from Strange Cases: Democracy, Development, and the Resource Curse in the US States. Comparative Political Studies 41:477-514.

Greene, William. 2010. Testing Hypotheses About Interaction Terms in Nonlinear Models. Economics Letters 107:291-96.

Haber, Stephen, and Victor Menaldo. 2011. Do Natural Resources Fuel Authoritarianism? A Reappraisal of the Resource Curse. American Political Science Review 105 (1):1-26.

Heston, Alan, Robert Summers, and Bettina Aten. 2012. Penn World Table Version 7.1. Center for International Comparisons of Production, Income and Prices at the University of Pennsylvania. Accessed 18 November 2012.

Jensen, Nathan M., and Leonard Wantchekon. 2004. Resource Wealth and Political Regimes in Africa. Comparative Political Studies 37 (7):816-41.

Kelley, Judith. 2008. Assessing the Complex Evolution of Norms: The Rise of International Election Monitoring. International Organization 62:221-55.

Kersting, Erasmus, and Christopher Kilby. 2014. Aid and Democracy Redux. European Economic Review 67:125-43.

Kilby, Christopher. 2009. The Political Economy of Conditionality: An Empirical Analysis of World Bank Loan Disbursements. Journal of Development Economics 89 (1):51-61.

Knack, Stephen. 2004. Does Foreign Aid Promote Democracy? International Studies Quarterly 48: 251-66. 
Kono, Daniel Yuichi, and Gabriella R. Montinola. 2009. Does Foreign Aid Support Autocrats, Democrats, or Both? Journal of Politics 71 (2):704-18.

Marshall, Monty G., and Keith Jaggers. 2011. Polity IV Project: Political Regime Characteristics and Transitions, 1800-2010. Dataset Users' Manual. Center for Systemic Peace. College Park: University of Maryland. Available at http://www.systemicpeace.org/polityproject.html. Accessed 1 March 2012.

Morrison, Kevin M. 2007. Natural Resources, Aid, and Democratization: A Best-Case Scenario. Public Choice 131 (3/4):365-86.

- 2009. Oil, Nontax Revenue, and the Redistributional Foundations of Regime Stability. International Organization 63 (1):107-38.

Pack, Howard, and Janet Rothenberg Pack. 1990. Is Foreign Aid Fungible? The Case of Indonesia. Economic Journal 100 (399):188-94.

Radelet, Steven. 2003. Bush and Foreign Aid. Foreign Affairs 82 (5):104-17.

Ramsay, Kristopher. 2011. Revisiting the Resource Curse: Natural Disasters, the Price of Oil, and Democracy. International Organization 65 (3):507-29.

Ross, Michael L. 2001. Does Oil Hinder Democracy? World Politics 53 (3):325-61.

2008. Oil, Islam, and Women. American Political Science Review 102 (1):107-23.

. 2012. The Oil Curse: How Petroleum Wealth Shapes the Development of Nations. Princeton, NJ: Princeton University Press.

Smith, Alastair. 2008. The Perils of Unearned Income. Journal of Politics 70 (3):780-93.

Stone, Randall W. 2002. Lending Credibility: The International Monetary Fund and the Post-Communist Transition. Princeton, NJ: Princeton University Press.

2008. The Scope of IMF Conditionality. International Organization 62 (4):589-620.

2010. Buying Influence: Development Aid Between the Cold War and the War on Terror. Unpublished manuscript, University of Rochester, NY.

Tilly, Charles. 1990. Coercion, Capital, and European States, AD 990-1992. Cambridge, MA: Blackwell.

Ulfelder, Jay. 2007. Natural Resource Wealth and the Survival of Autocracy. Comparative Political Studies 40 (8):995-1018.

USAID. 2010. US Overseas Loans \& Grants Greenbook. Available at https://www.usaid.gov/developer/ greenbookapi. Accessed 29 September 2015.

Vreeland, James Raymond. 2011. Foreign Aid and Global Governance: Buying Bretton Woods the Swissbloc Case. Review of International Organizations 6 (3-4):369-91.

Wright, Joseph. 2009. How Foreign Aid Can Foster Democratization in Authoritarian Regimes. American Journal of Political Science 53 (3):552-71. 